\title{
Article
}

\section{North Korea: Market opportunity, poverty and the provinces}

\author{
Smith, Hazel Anne
}

Available at http://clok.uclan.ac.uk/10518/

Smith, Hazel Anne (2009) North Korea: Market opportunity, poverty and the provinces. New Political Economy, 14 (2). pp. 231-256. ISSN 1356-3467

It is advisable to refer to the publisher's version if you intend to cite from the work.

For more information about UCLan's research in this area go to http://www.uclan.ac.uk/researchgroups/ and search for <name of research Group>.

For information about Research generally at UCLan please go to http://www.uclan.ac.uk/research/

All outputs in CLoK are protected by Intellectual Property Rights law, including Copyright law. Copyright, IPR and Moral Rights for the works on this site are retained by the individual authors and/or other copyright owners. Terms and conditions for use of this material are defined in the policies page.

\section{CLoK}

Central Lancashire online Knowledge www.clok.uclan.ac.uk 


\title{
North Korea: Market Opportunity, Poverty and the Provinces
}

\author{
HAZEL SMITH
}

A process of 'marketisation without liberalisation' has been taking place in the Democratic People's Republic of Korea (DPRK or 'North Korea') since the mid 1990s; so called because the transformation of the North Korean political economy from state to market was a bottom-up process and was not accompanied by political liberalisation from the government downwards (Center for Contemporary International Problems 1997; Smith 1999, 2002, 2005a). ${ }^{1}$ We have little understanding, however, of how that economic transformation has been sustained domestically since the mid 1990s to present (2009). This article aims therefore to show how and why that transformation became embedded in the way it did (and not in any other way). The focus is on provincial differences to illustrate the differential way in which marketisation became embedded in North Korean society and the consequences of post-famine marketisation.

The analysis builds on previous work in which the author evaluated the socioeconomy of North Korea in terms of the famine that ravaged the country in the mid 1990 s as a causative agent of economic transition (Smith 2002, 2005a). It also builds on work where the author argued that the inadvertent role of local branches of the, effectively, only party in the DPRK, the Korean Workers' Party (KWP), was to promote economic and social change and to act as 'legitimator' of the new economic and social practices that emerged from that period of transformation in North Korean social history (Smith 2005b). This approach therefore takes issue with the common-knowledge approach to studying North Korea, which assumes that the state and society are homogeneous and unchanging. ${ }^{2}$ Provincial differences, for instance, in the areas of agricultural productivity and in nutritional status of the population, can be quantified and demonstrated, as can their change over time.

The advent of provincial inequality should hardly be a surprise to those who have studied the DPRK and understand that, as with so many other states that lost economic subsidies after the Soviet Union collapsed, the North Korean state lost its resource base and also its capacity to distribute rewards and punishments and thus maintain central state control over the population. In the vacuum generated by the incapacity of the central state authorities, it is hardly surprising that those regions that could and did find ways to look after themselves and their

Hazel Smith, Department of Applied Science, Security and Resilience, DASSR - WH229, Cranfield University, Shrivenham Campus, Swindon SN6 8LA, UK.

ISSN 1356-3467 print; ISSN 1469-9923 online/09/020231-26 (C) 2009 Taylor \& Francis DOI: $10.1080 / 13563460902826005$ 
populations did manage to recover economically, and those with less capacity did not, thus generating inequality between provinces (Asad et al. 2005).

What is perhaps surprising is that difference in deprivation between provinces was not a direct function of relative agricultural self-sufficiency in the post-famine years, although there may be an argument to show that this was formerly the case in the pre-famine years. ${ }^{3}$ This conclusion challenges the conventional assumptions of the policy community. In 2004, for instance, the United Nations Food and Agriculture Organization (FAO) was arguing that farmers should not receive humanitarian food aid because

[t]hanks to farmers' relatively high rations, better access to kitchen gardens and hill side plantations, as well as their individual share of the farm's income resulting from the sale of surplus food to the Government or on the local markets, their food situation is far better than that of PDS [Public Distribution System] dependent households. (FAO/WFP (UN World Food Programme) 2004a: 17)

During and after the famine of the mid 1990s, in the absence of state capacity, local party and state officials and workplaces improvised. Working with diverse natural endowments and comparative advantages, they called on legitimacy principles of local self-reliance inherited from the now long-gone socialist period. ${ }^{4}$ Tracing how these capitals intersected with market opportunities provides the explanatory framework for understanding the differential survival opportunities and social and economic reconstruction paths that became available for different social groups. This framework functions to explain inequality for all social groups in post-famine North Korea, whether defined by age, gender, occupation or regional provenance. In this article, however, I focus on geographical location and use the province as the main unit of analysis.

It is shown that assumptions that are founded on a view that farmers and farming provinces are likely to be better off than other sectors and provinces are questionable at best and inaccurate at worst. Provincial agricultural selfsufficiency was not the only or even in some cases the major determinant of either relative nutritional status of the provinces or a direct reflection of agricultural capacity within the province. It is also shown that provincial agricultural insufficiency in some cases could be compensated partly by market opportunities. The extreme example, also demonstrated in this article, is where provincial agricultural self-sufficiency was not reflected in better (against other provinces) or good (in terms of the provincial population) nutritional outcomes.

\section{The knowledge base, the data and the terminology}

There is now available a knowledge base about the North Korean economy that is qualitatively and quantitatively a huge improvement on that available even at the end of the 1990s, much of it coming from the international humanitarian and development organisations that have worked in the DPRK since the mid 1990s. The knowledge base on North Korea is also supported by plethora of blogs and websites whose main aim is to collate information on the DPRK economy. ${ }^{5}$ 
Much of the best analysis of the North Korean economy is anchored in the policy realm (see for example Kim 2007; Cho 2007; Suh 2008; KINU Insight 20072008; International Journal of Korean Unification Studies (1992-2008); Lee and Yoon 2004; Ahn 2007; Korea Economic Institute nd). We have seen much less scholarly analysis of economic transformation to the marketisation that characterises today's North Korea (exceptions include Frank 2006, 2008). This is a pity because it means for instance that potentially useful comparative analysis that might be available from a study of transformation to market systems in other Communist countries, including North Korea's neighbour and ally, China, is not being developed (McNally 2007).

Data are drawn from DPRK government sources as made available to international organisations (UNICEF 1997; Central Bureau of Statistics/UNDP 1998; USAid 1998; UNICEF 1999a; Flood Damage Rehabilitation Commission 2000; WFP 2000, 2001, 2006). The data are that deemed credible and more or less reliable by the major international organisations and are a conventional source for academic and policy analysis. The data used are those which are therefore at the time of writing (2008) informing international organisations, government and non-governmental organisation (NGO) policy and practice towards the DPRK. What this article offers therefore is not new data per se, but a new interpretation of existing data.

It is understood that (provincial) agricultural self-sufficiency occurrs if the province produces enough grain to feed its population at the FAO minimum living standard of $167 \mathrm{~kg}$ per capita. ${ }^{6}$ Agricultural self-sufficiency in this article therefore implies an ability to feed the (provincial) population from (provincial) domestic production if the grain produced by the province remains within the province. Nutritional status is assessed in terms of the standard nutritional category of 'wasting', that is, low weight for height (see UNICEF 1999b). Wasting is a sign of acute malnutrition and is a useful proxy indicator to show the continuation of famine conditions in proportions of a population. The time focus of this article is 2002 to 2004 , that is, the period of post-famine agricultural and economic development that was characterised by relative economic stabilisation, albeit at low levels of economic activity (Korea Economic Institute 2008).

Economic breakdown and poverty were most visible in terms of food shortages and their direct effects on the populations' nutritional and health status. Therefore the nutritional status of the population is used as a proxy indicator for poverty and economic deprivation. It is not argued, however, that aggregate food shortages were the only cause of malnutrition of individuals. Poor sanitation, compromised water supplies and lack of access to medicines can be equally important in terms of determining who might succumb to illness and disease. In North Korea, however, where nationwide surveys found that almost the entire population suffered from compromised water and sanitation supplies and lack of access to medicines, provincial differentiation in terms of nutritional status was unlikely to be a direct result of better or worse endowments in these sectors. ${ }^{7}$

\section{The provinces}

In the DPRK local government administration is tiered with the provinces as the highest level of local authority - for a map, see Figure $1 .^{8}$ The counties provide 


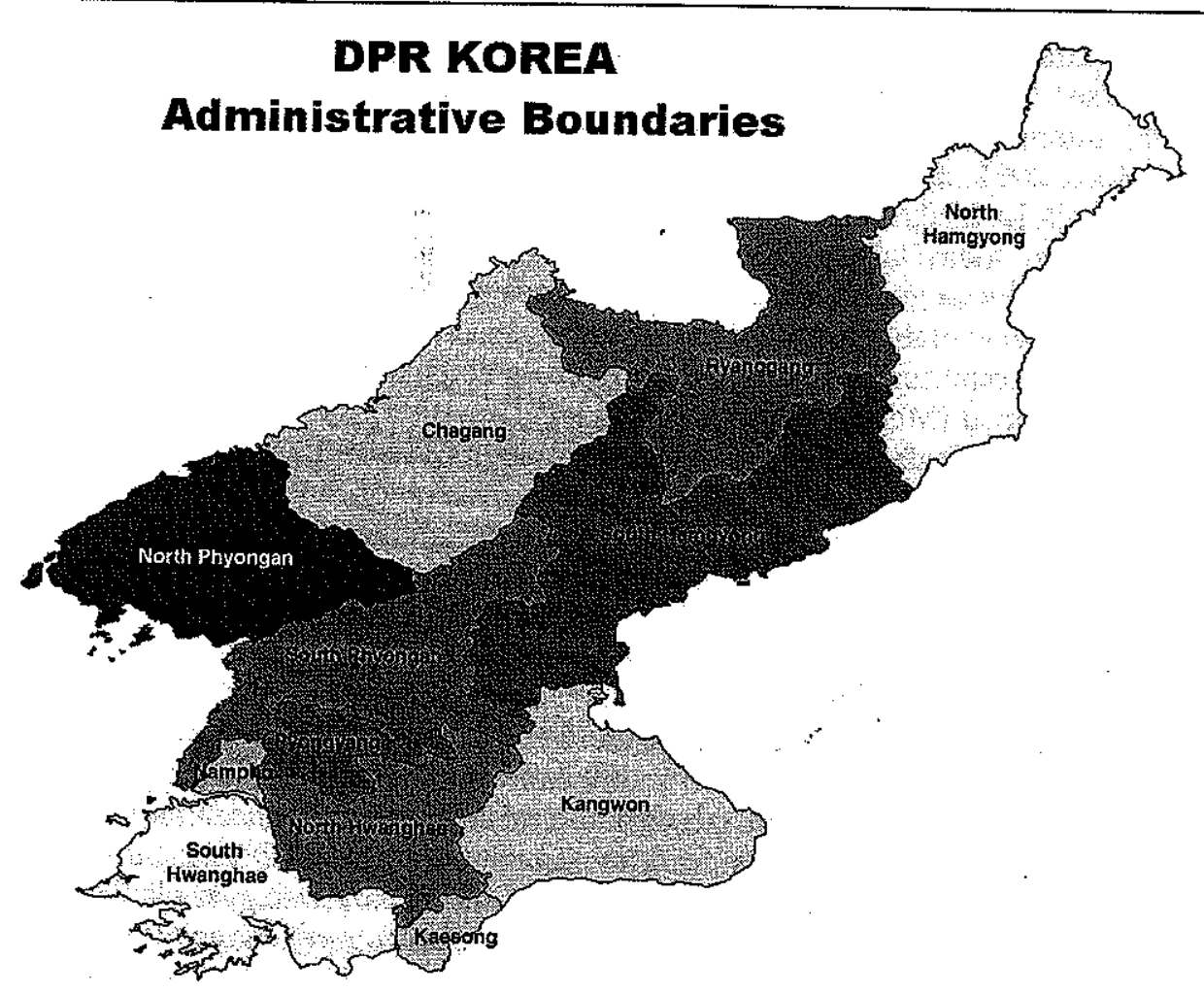

FIGURE 1. DPRK provincial administrative boundaries (2004).

the next level of local government authority. Counties are divided into smaller geographical areas, known as the $r i$ in the rural areas and the dong in the urban areas. The $r i$ and the dong, however, are merely administrative divisions and are not repositories of local government authority.

Until 2004, North Korean local government was organised via nine provinces and three Cities of Central Authority (CCAs), with the latter having equal administrative status to the provinces. The analysis in this article is based therefore upon this 12-province structure. For the record however, it should be noted that in late 2004 the DPRK reorganised its administrative structure such that two of the CCAs, Kaesong and Nampo, were incorporated into the provinces of North Hwanghae and South Pyongyan, respectively. In 2009, the DPRK organises local administration around a ten-province structure, although there remains uncertainty as to the final shape of the new DPRK local government administrative structure. Kaesong for instance, where South Korea has invested in a new industrial zone, has been given a special status by the DPRK authorities with special legislation appertaining to it.

Figure 2 sets out the post-2004 provincial population totals for ten provinces (as supplied by the DPRK government to the UN World Food Programme in 2005 - see WFP (2006)). The same source shows total population figures for the DPRK in 2005 at 22.9 million. 


\section{Hazel Smith}

externally validated nutrition survey carried out in 1988 in Kangwon, one of the provinces whose population suffered particularly badly from famine and its aftermath, showed no discernible difference between the rural and urban areas in the province in terms of nutritional status of children (UNICEF/Institute of Child Nutrition 1988).

To be sure the privileged class around the ruling Kim family in Pyongyang had access to food and luxury goods from abroad, but this numerically small part of the population was not representative of the majority of the population of Pyongyang. Neither was this small Pyongyang-based elite representative of the majority of party members simply by virtue of the fact that the Korean Workers' Party was a mass party, in its heyday incorporating possibly half the adult male population. ${ }^{12}$ Party members throughout the country were just as likely to be faring badly in the new market economy as non-party members given the state could no longer afford to guarantee food and basic goods to the population and state and party officials.

\section{Agricultural self-sufficiency differentials between provinces in the post-famine period}

The most reliable figures as to agricultural production came from the twice yearly food and crop assessment reporting from the FAO. ${ }^{13}$ It is not argued that FAO always got it right in defining the problems - merely that the data are reasonably consistent and usable as a reliable source. FAO have in the main been very careful not to use the data available to them to analyse anything other than the specific task set at the time of each mission, in other words to provide 'snap-shot' analysis. This is partly because the FAO, in any country in which it works and perhaps especially so in the DPRK, has been hyper-sensitive to any possible charges that it is collecting data for purposes other than those stated. My use of FAO data therefore does not always end up with similar conclusions drawn by FAO and the WFP from the same data.

FAO/WFP guidelines for the basic food necessities for survival for an adult are something like 1600 calories a day (FAO/WFP 1999). The cheapest way of providing calories is from the production of basic cereals, including rice, maize (corn), millet and potatoes. Cereal availability from production, imports and aid is therefore often used by donor governments and agronomists alike as a proxy indicator for measuring the availability of sufficient food for survival purposes for a given population. In the DPRK the rule-of-thumb figure used to measure food availability for survival needs was $167 \mathrm{~kg}$ per person per year (FAO/WFP 2002). FAO reporting shows that in the post-famine years some provinces were better able to meet the basic food requirements of their populations from their own production than others.

Data are drawn together in Figure 3 that illustrate which provinces recovered from the famine period such as to rebuild agricultural self-sufficiency and which could not do so. Not surprisingly, Figure 3 shows that the 'breadbasket' province (that is the province with the largest amount of cultivable land) of South Hwanghae was most successful in regaining agricultural self-sufficiency with North Pyongan and North Hwanghae, both 'mixed' agricultural and industrial 
le of the

its after-

is in the

ff Child

'ang had

1 part of ation of

e of the

Korean

half the

just as

lembers

Is to the

e yearly at FAO sonably careful specific nalysis. perhaps charges Jf FAO y FAO

dult are of pro- maize and aid a proxy urposes neasure )/WFP as were $\mathrm{m}$ their

:overed cy and et' proE South :y with Iustrial
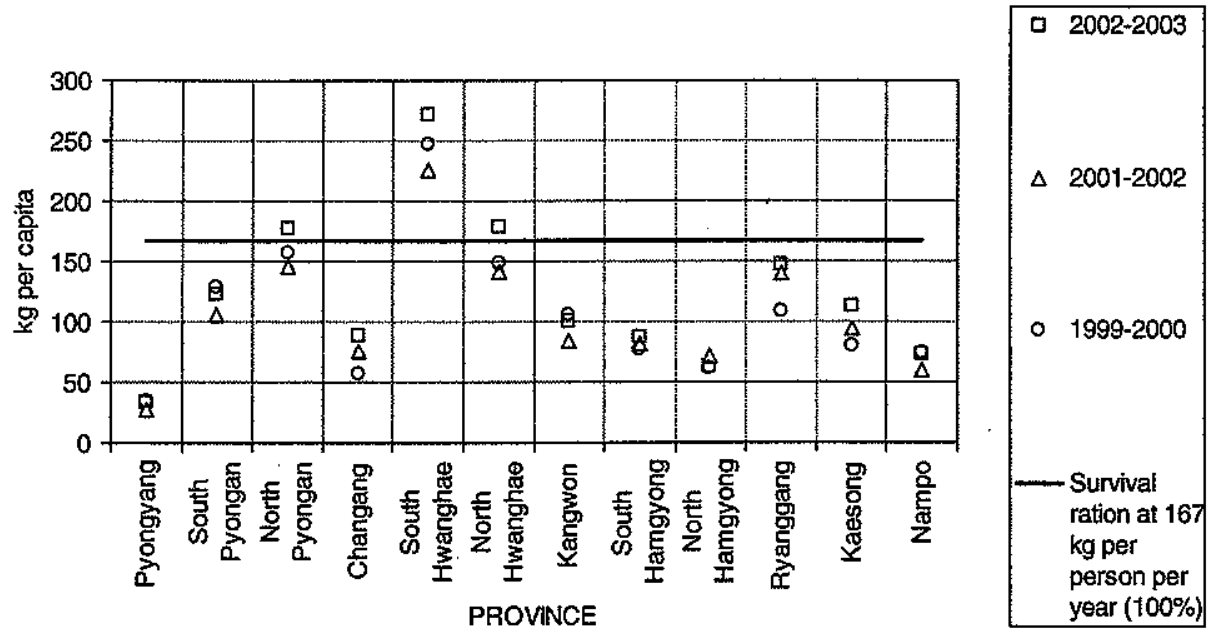

FIGURE 3. DPRK per capita availability of cereals from provincial production (kg). Source: Figures derived from FAO, FAO worksheet on DPR Korea agriculture, 26 October 1999; FAO, FAO/ GIEWS Special Report on Korea DPR - 12 October 2001; FAO, FAO worksheet on DPR Korea agriculture, 16 October 2002.

provinces not far behind. ${ }^{14}$ Ryanggang, which benefited from massive state and some foreign investment in potato farming during the late 1990s, also crept up near to the minimal self-sufficiency level of being able to provide $167 \mathrm{~kg}$ in cereal per person per year for its population. Figure 3 shows that from 1999 onwards the provinces established a pattern of agricultural production that, irrespective of the figures achieyed per annum, demonstrated a fairly stable pattern of relative agricultural capacity.

TABLE 1. Agricultural self-sufficiency ranking per province, 2002-3

\begin{tabular}{lc}
\hline Province & Agricultural self-sufficiency ranking \\
\hline South Hwanghae & 1 \\
North Hwanghae & 2 \\
North Pyongan & 3 \\
Ryanggang & 4 \\
South Pyongan & 5 \\
Kaesong & 6 \\
Kangwon & 7 \\
Chagang & 8 \\
South Hamgyong & 9 \\
Nampo & 10 \\
North Hamgyong & 11 \\
Pyongyang & 12 \\
\hline
\end{tabular}

Source: Figures derived from FAO worksheet on DPR Korea agriculture, 16 October 2002. 


\section{Hazel Smith}

Figure 3 shows that only three of the country's 12 provinces could produce enough food to feed their population by 2002-3 and only one province, South Hwanghae, consistently was able to produce enough food to feed its population. Figure 3 also shows that by 2002-3 the worst-off provinces in terms of cereal production were respectively Pyongyang, North Hamgyong, Nampo, South Hamgyong, Chagang and Kangwon, which remained unable to guarantee a level of cereal ration at even $100 \mathrm{~kg}$ per person a year, while the populations of Kaesong and South Pyongan were not much better off.

In simple ranking in terms of potential agricultural provincial self-sufficiency, South Hwanghae was the best able (number 1 in the ranking) and Pyongyang the least able (number 12 in the ranking) to feed their population by farming in year 2002-3. Table 1 shows the relative ranking of the provinces in 2002-3 in terms of their ability to feed their own populations from provincial grain production.

\section{Nutritional status of the provinces}

Figure 4 gives the extant information on the nutritional status of children under 7 years old in 2002 and 2004 in terms of 'wasting' - that is, low weight for height. Data is available on nutritional status for both 2002 and 2004 for eight of the 12 provinces therefore comparisons are restricted to these eight provinces. The figure is based on data on the nutritional status of children under 7 years old (Central Bureau of Statistics 2002; Central Bureau of Statistics/Institute of Child Nutrition 2005).

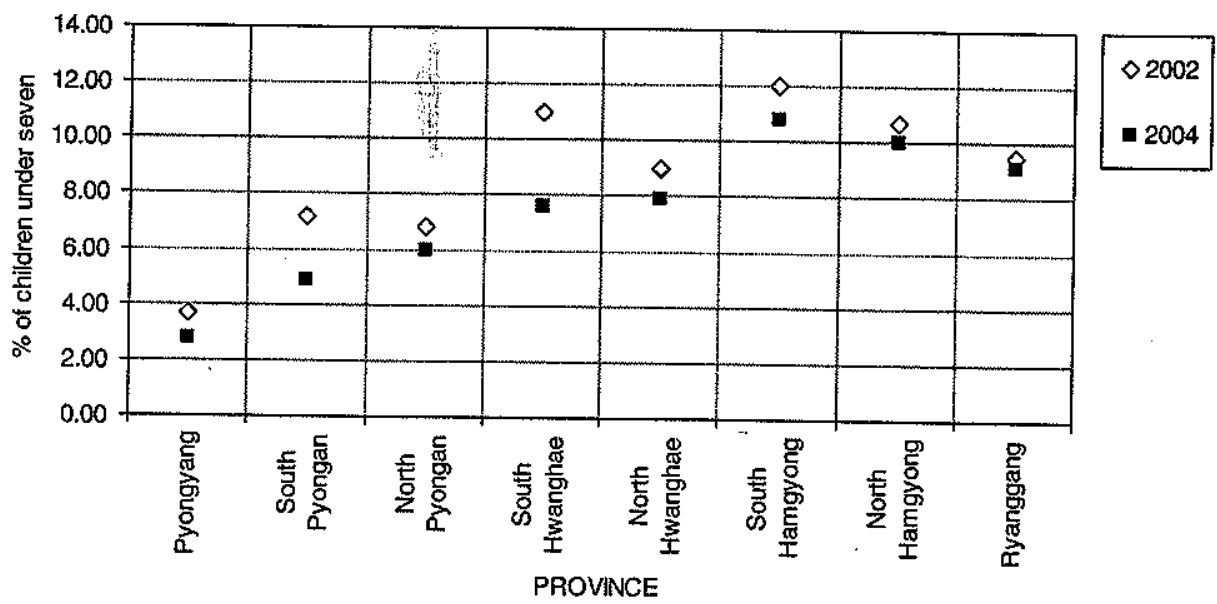

FIGURE 4. Wasting (low weight for height) in children under 7 years old in 2002 and 2004 Source: Figures derived from Central Bureau of Statistics 2002 and February 2005.

The nutrition survey of 2004 took place in October of that year. The report from the 2004 nutrition survey explicitly states that nutrition survey results for years 2002 and 2004 can be compared across provinces (Central Bureau of Statistics/ 
produce e, South ulation. of cereal ', South rantee a ttions of

ficiency, ongyang farming 2002-3 al grain

in under ight for or eight ovinces. 'ears old of Child

and 2004 . 15.

ort from or years atistics/

North Korea: Market Opportunity, Poverty and the Provinces

TABLE 2. Nutritional status ranking per province 2004 and 2002

\begin{tabular}{lcc}
\hline Province & $\begin{array}{c}\text { Nutritional status } \\
\text { ranking 2004 }\end{array}$ & $\begin{array}{c}\text { Nutritional status } \\
\text { ranking 2002 }\end{array}$ \\
\hline Pyongyang & 1 & 1 \\
South Pyongan & 2 & 3 \\
North Pyongan & 3 & 2 \\
South Hwanghae & 4 & 7 \\
North Hwanghae & 5 & 4 \\
Ryanggang & 6 & 5 \\
North Hamgyong & 7 & 6 \\
South Hamgyong & 8 & 8 \\
\hline
\end{tabular}

Source: Figures derived from Central Bureau of Statistics, February 2005, 2002.

Institute of Child Nutrition 2005). It does not mention country reorganisation as a complicating or relevant factor in analysis of the nutrition survey results. As the same nutritionists from UNICEF led both the 2002 and 2004 survey and would have been expected to note discrepancy in surveys that invalidated comparisons, this article accepts the validity of these comparisons of nutritional status across 2002 and 2004. The nutritional ranking for the eight provinces for which we have data is shown in Table 2.

If provincial agricultural self-sufficiency were the only or major determinant of food poverty, one would expect that relative nutritional deprivation would closely follow the ranking of provinces as outlined in Table 1. Pyongyang would have the worst levels of malnutrition in the post-famine period and South Hwanghae the least nutritional problems. Table 2 shows, however, Pyongyang had the best level of nutritional status and not the worst.

\section{Comparing agricultural self-sufficiency with nutritional status}

In this section the disparities are analysed between provincial nutritional status and agricultural self-sufficiency. Nampo, Kaesong, Kangwon and Chagang are excluded from the comparisons in this section because nutritional data are not available for those provinces for both 2002 and 2004. In order to illustrate the discrepancy between agricultural self-sufficiency and nutritional status a simple contrast is first shown between the agricultural self-sufficiency ranking for 2002-3 with nutritional status ranking for 2002 and 2004 .

Figure 5 shows that there is no simple correlation between provincial agricultural self-sufficiency and provincial nutritional status. Pyongyang is the province with the least agricultural production but consistently the best-off province in terms of nutritional status of children. South Hwanghae in 2002 was the second worst province in terms of nutritional status and the best in terms of agricultural self-sufficiency.

The simple ranking correlations shown in Figure 5 tell us nothing, however, about the real scale of the discrepancy between agricultural self-sufficiency per province and the nutritional status of the population of each province as it 
merely shows contrast in numerical ranking. We thus need to find a way of measuring the discrepancies based on real values, that is, per capita grain production and percentages of wasting per province. Next, therefore, an agricultural self-sufficiency index (Is) and a nutritional index $(I n)$ per province is built and the ratio between the two is calculated. The ratio between the two indices provides an actual measure of the disequilibila between agricultural self-sufficiency and nutritional status for each province. (If the nutritional status was proportional to cereal production the $I_{s} / \operatorname{In}$ ratio would be the same for each province.) The data produced quantify a measurable disequilibria between agricultural self-sufficiency and nutritional status.

This further analysis of the data illustrates the very dramatic disparities between provinces in a way that a simple rank ordering comparison cannot. It shows the scale of the disparity between agricultural self-sufficiency and nutrition. It is the scale of the disparity as much as the simple ranking non-correlation between provinces that is the surprising, perhaps startling, outcome of this analysis. It is also the scale of disequilibria that perhaps should cause some concern for policy makers.

\section{Agricultural self-sufficiency indices for eight provinces in the DPRK, 2002-3}

Figure 6 constructs an agricultural self-sufficiency index $(I s)$ for eight provinces in the DPRK. The agricultural self-sufficiency index $(I s)$, is the ratio between the grain production per capita for each of the eight provinces and the grain production per capita in South Hwanghae. South Hwanghae is used as the reference province because it is the province with the highest per capita cereal availability for food from provincial production. The index for each province is obtained by dividing the per capita availability of cereal for food from provincial production

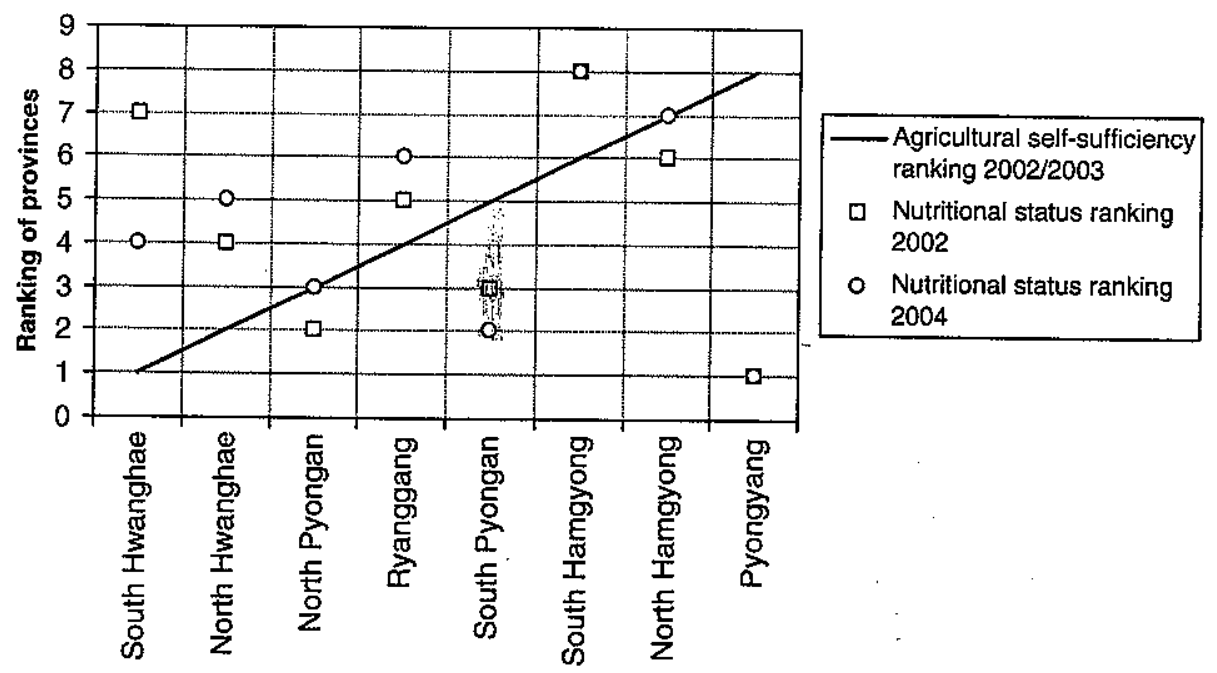

FIGURE 5. Ranking of provinces by agricultural self-sufficiency and nutritional status, 2002-4. Source: Figures derived from Central Bureau of Statistics, February 2005, 2002 and FAO worksheet on DPR Korea agriculture, 16 October 2002. 
by the per capita availability of ceteal for food from South Hwanghae (the reference province). The value of this index is thus equal to one for South Hwanghae and less than one for all the other provinces.

\section{Nutritional indices for eight provinces in the DPRK, 2002 and 2004}

Figure 7 constructs a nutritional index (In) for eight provinces in the DPRK. The nutrition index $(I n)$ is the ratio between the nutritional status of each of the eight provinces and the nutritional status of South Hamgyong. South Hamgyong, the province with the highest percentage of children under 7 years old categorised as wasted in both 2002 and 2004 (that is the worst nutritional status), is used as the reference province. The index for each province is obtained by dividing the malnutrition rate for South Hamgyong by the malnutrition rate for each province (including itself). The value of this index is thus equal to one for South Hamgyong and more than one for all the other provinces. We have thus converted values for malnutrition into nutrition indices. The nutrition index $(I n)$ is the ratio between the highest percentage of wasting in children under 7 years old and the percentage of wasting of children in every province.

\section{Ratio between indices of agricultural self-sufficiency and nutritional status}

Figure 8 shows the ratio between the nutrition index (In) and the agricultural selfsufficiency index $(I s)$ for eight provinces in the DPRK for the years 2002 and 2004. The figures give a value for the ratio between the two indices we have constructed above. High values indicate a relatively good nutritional status in provinces with low agricultural self-sufficiency. In crude terms, high values show that the population eats more and produces less. Low values indicate poor nutritional status in provinces with relatively high agricultural self-sufficiency. In crude terms low values mean the population eats less and produces more. (If the nutritional status of every province was proportional to its agricultural self-sufficiency then the ratio would be the same for each province.)

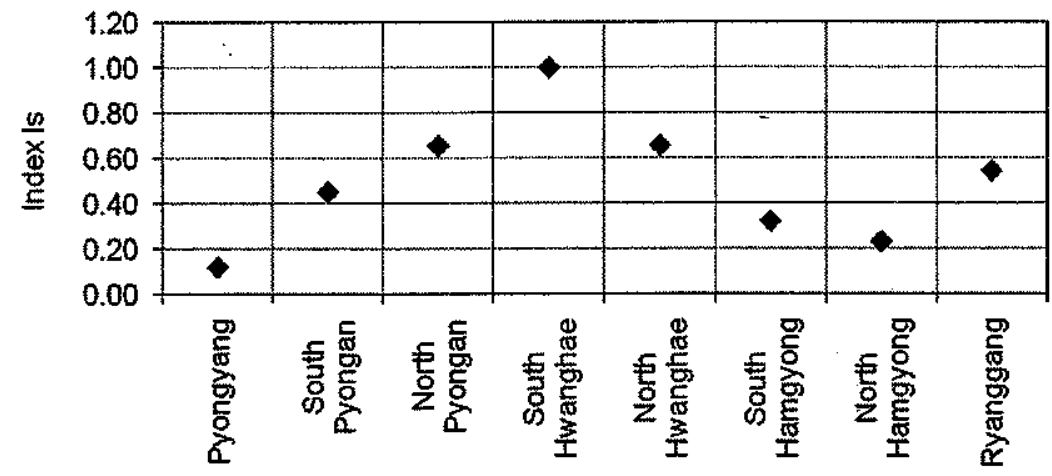

FIGURE 6. Agricultural self-sufficiency index (Is) for eight provinces in the DPRK for 2002-3. Source: Figures derived from FAO worksheet on DPR Korea agriculture, 16 October 2002. 


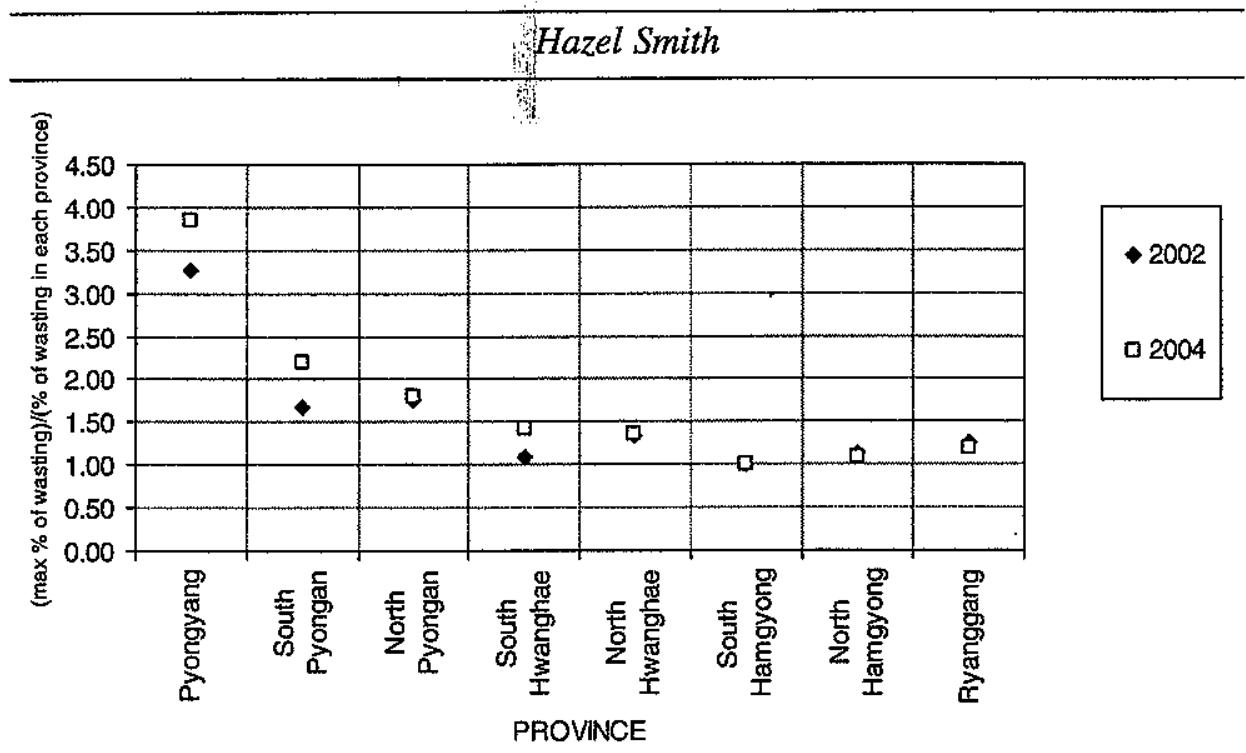

FIGURE 7. Nutrition index (In) for eight provinces in the DPRK for 2002 and 2004. Source: Figures derived from Central Bureau of Statistics, 2002 and February 2005.

The value for Pyongyang is so extreme that it distorts the scale. For this reason the same data is reproduced in Figure 9 but Pyongyang is excluded.

We can see from the simple ranking comparison in Figure 5 that South Hwanghae, the best-off province in terms of agricultural production, and which since at least 1999 had produced an agricultural surplus (see Figure 3), was the second to the worst performer in terms of nutritional status of children in 2002 and had improved its ranking in nutritional status to only fourth (out of the eight provinces) in 2004. Figures 7 and 8, however show that, not only was it relatively poorer than provinces with less ability to feed their populations from their

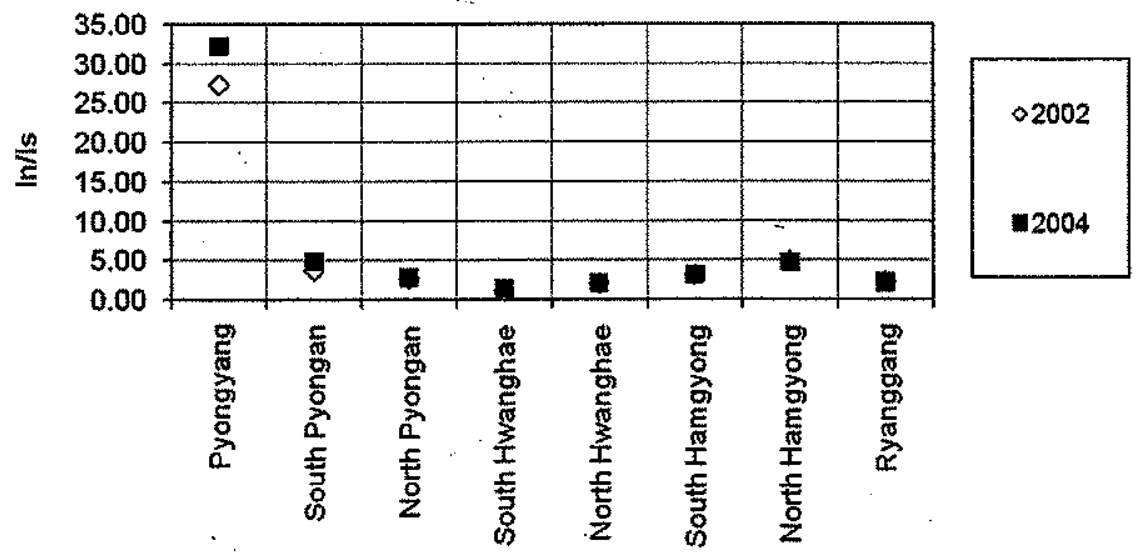

FIGURE 8. Ratio between indices of nutritional status and agricultural self-sufficiency for eight provinces (2002 and 2004). Source: Figures derived from Central Bureau of Statistics, February 2005, 2002 and FAO worksheet on DPR Korea agriculture, 16 October 2002. 
own production but that it was consistently the worst-off province of all eight in terms of the relationship of nutritional status to agricultural self-sufficiency.

Figure 9 indicates further counter intuitive results. We know from Figure 5 that North Hwanghae, the second best agricultural producer in 2002-3, had nutritional indicators worse than three of eight provinces in 2002 and four of eight in 2004. Figure 9 further demonstrates that in terms of the rátio between nutritional status and agricultural self-sufficiency, North Hwanghae was the second worst performer in both 2002 and 2004.

Another surprising finding is that North Hamgyong, the remote province in the north-east, second only to Pyongyang in its inability to feed its population from its own agricultural production, does not show the worst disproportionality between nutritional status and agricultural self-sufficiency. Table 2 indicates that North Hamgyong was sixth place (out of eight provinces) in terms of nutritional status in 2002 and seventh in 2004. Figure 9 indicates also that in terms of ratio between nutritional status and agricultural self-sufficiency, the province was doing much better than either of the breadbasket provinces of South Hwanghae or North Hwanghae. The health warning with these results should be a reminder (see Figure 4) that malnutrition rates remained higher in North Hamgyong than South Hwanghae and North Hwanghae in 2004 (though not in 2002 when the malnutrition rate for South Hwanghae was higher than North Hamgyong). Nevertheless the puzzle remains as to why North Hamgyong was not even worse off. We also can find again a perhaps puzzling result in that South Hamgyong, another north-eastern province but with better agricultural self-sufficiency than North Hamgyong, proved to have the worse nutritional indicators in both 2002 and in 2004 (see Figure 5). Figure 9 indicates that South Hamgyong was also worse off than North Hamgyong in terms of its ratio between nutritional status and agricultural self-sufficiency. Why was it less able to feed its population than North Hamgyong, a province with worse agricultural capacity?

Figures 5, 8 and 9 demonstrate therefore some rather predictable results as well as some surprising outcomes. Not surprisingly the data demonstrates that Pyongyang the capital city is consistently much better off in relative terms than the other provinces. More surprising results are that North Hamgyong, generally understood as the worst-off provine in the country in terms of agricultural selfsufficiency and the nutritional status of the population, fared better than the common knowledge. would presume. ${ }^{15}$ Very surprisingly, Figures 8 and 9 also indicate that the breadbasket provinces of South Hwanghae and North Hwanghae were the two worst-off provinces in the country in terms of the relationship of nutritional status to agricultural self-sufficiency. In other words the fact of living in a breadbasket province was not as advantageous to the population as might have been presumed.

\section{Market opportunities and provincial inequality}

In this section the focus is on three discrete research puzzles identified in the first section of this paper regarding the economic well-being of the populations of South Hwanghae, North Hamgyong and South Hamgyong. It has been already shown that provincial agricultural self-sufficiency does not correlate with 
Hazel Smith

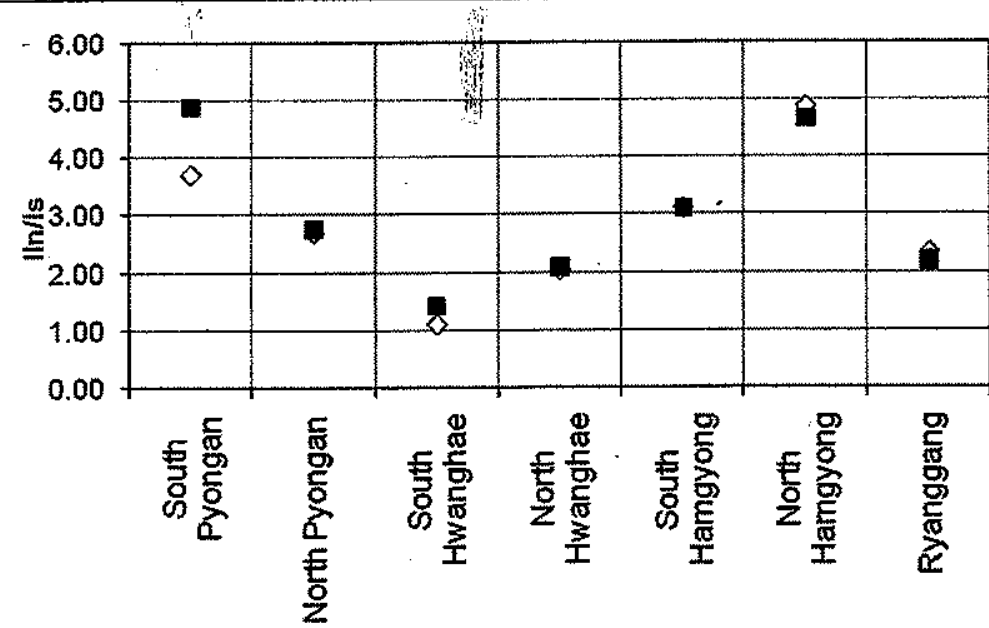

FiguRe 9. Ratio between indices of nutritional status and agricultural self-sufficiency for seven provinces (excluding Pyongyang), 2002 and 2004. Source: Figures derived from Central Bureau of Statistics, February 2005, 2002 and FAO worksheet on DPR Korea agriculture, 16 October 2002.

provincial nutritional status and therefore is not the key factor in determining poverty outcomes. It is hypothesised, therefore, that in the post-famine period relative deprivation between provinces was and is the outcome of the relationship between comparative advantage, including agricultural self-sufficiency, and market opportunity. It is suggested that (non-mutually exclusive) relevant variables in explaining economic welfare of the provinces were (i) proximity to foreigners and consequently hard currency and non-state sanctioned opportunities to buy and sell food and (ii) the degree of state control over local populations and non-state sanctioned trading opportunities. This hypothesis cannot be fully investigated in the confines of this essay but it is hoped that the directions suggested provide a potentially fruitful avenue for further research.

South Hwanghae was the best-off province in terms of agricultural production and since at least 1999 had produced an agricultural surplus (see Figure 3). The first research puzzle is, then, why was South Hwanghae consistently the worstoff province of all eight provinces surveyed (Figures 8 and 9) in terms of the relationship of nutritional status to agricultural self-sufficiency? Why did the population of South Hwanghae fare so badly in absolute terms in respect of nutritional status? Why was South Hwanghae the second worst performer in terms of nutritional status of children in 2002 and had improved its ranking in nutritional status to only fourth (out of the eight provinces) in 2004?

The second research puzzle relates to North Hamgyong, second only to Pyongyang in its inability to feed its own population. Why was the population of North Hamgyong not the worst-off in terms of nutritional indicators? Why did North Hamgyong, in terms of the ratio between nutritional status and agricultural self-sufficiency, do much better than either of the breadbasket provinces of South Hwanghae or North Hwanghae?

South Hamgyong is a similarly industrialised province to North Hamgyong, but with a better ability to feed its population from its own grain production. Why was 
South Hamgyong then the worst performer in terms of nutritional indicators in both 2002 and in 2004? Figures 8 and 9 show, however, that relative to its per capita food production, the nutrifional indicators of the population are better than those of South Hwanghae, North Hwanghae, North Pyongan and Ryangan. The further question arises then as to why South Hamgyong was not faring even worse than it was.

Before turning to these three research puzzles I first summarise the changes in the North Korean economy since the famine of the early and mid-1990s. Next I discuss the special position of Pyongyang. I discuss the phenomena of international food aid and whether this may have made a difference to provincial outcomes and disparities.

\section{Marketisation without political liberalisation}

zy for seven ntral Bureau ictober 2002.

stermining eriod rela:lationship ency, and :vant variximity to sortunities ations and lly invessuggested roduction re 3). The he worstms of the $y$ did the t of nutri1 terms of uutritional

1 only to opulation ors? Why d agriculvinces of yong, but Why was

North Korea underwent profound social and economic transformation after the famine of the mid-1990s that killed up to a million people. ${ }^{16}$ The 21 million North Koreans who survived the famine did so because, in the absence of the government's inability to feed, clothe and offer basic social services to the population after the economic collapse in the early 1990s, the only alternative to starvation was self-help (Smith 2005a; Haggard and Noland 2007; Reed 2008; Lee 2008; Lankov 2008; Smith 2008; Haggard and Noland 2008). Individuals engaged in private economic transactions, all outside of government purview. The state never regained economic capacity sufficient to re-establish state control of the production, supply and distribution of goods including food. Those individual private economic transactions therefore became institutionalised in a system of informal rules that it has been argued can be understood as a system of 'Marketisation without Liberalisation' (Smith 2005a).

North Korea is marketised, not because the population physically goes to market to purchase almost all basic needs, including food, although it does, but, much more importantly, because since the famine, North Korea's economics have been governed by the laws 1 f supply and demand. North Korea's move to the market has certainly not been accompanied, however, by a shift towards political liberalisation. Indeed the government has spent a great deal of domestic political decision-making time trying to find ways to prevent the spread of political freedoms that they fear could, without government intervention, spill over into the political arena.

In the mid 1990s the presence of formal and informal markets and the burgeoning parallel market for the local currency, the won, provided some of the evidence for marketisation (Center for Contemporary International Problems 1997). Evidence also came from the dozens of Chinese traders operating in the NorthEastern border area of North Korea. Households, local authorities, enterprises and individuals earned and obtained hard currency through all forms of nonstate sanctioned transactions. These included legitimate trading, including for instance lumber and herbs, but also less licit deals, such as selling off entire factories for scrap metal, smuggling and transborder trafficking into China of women for 'bride purchasing' or for work in bars and as prostitutes. 
For the hundreds of international aid, development and diplomatic personnel who lived and worked in Pyongyang from the mid 1990s for period of months up to several years, the process of marketisation was an obvious fact of everyday life with all shopping and most currency transactions increasingly openly carried out through market mechanisms. By the 2000 s. any pretence that the government was the primary provider of goods or had much to do at all with the prices at which goods were sold had been abandoned by both the government and the resident international workers who lived in the real world of the DPRK as opposed to the imaginary one of state propaganda (Hoare and Pares 2005).

\section{Pyongyang}

Pyongyang consistently demonstrates a radical mismatch between agricultural capacity and nutritional status with the province being the worst in the former category and the best in the latter. It might be tempting to argue that the data thus upholds the common knowledge perception of Pyongyang as a Potemkin city. This would be a superficial conclusion however as the data do not show an absence of malnutrition in Pyongyang (see Figure 4). The malnutrition figures for Pyongyang, although low compared to the other provinces, are not low in terms of the absolute numbers of malnourished children or compared to malnutrition figures from other countries. In 2002 just over 4 per cent of Pyongyang's population under 7 years old suffered from wasting. The 4 per cent figure amounted to 14,600 young children suffering from famine-like conditions (WFP 2003a). In China the equivalent figure for the entire country was 1 per cent and for the Philippines 6 per cent (Central Bureau of Statistics 2002).

Pyongyang's nutritional status is not further analysed as there is no research puzzle here. Despite the continuing presence of malnutrition, the data indicates that Pyongyang is doing better than other provinces. Given the importance of the capital city as the focus of business, governmental and international activity, this is hardly a surprising outcome. A methodological point worth noting, however, is that given the data sets and analysis support an empirically obvious outcome in relation to Pyongyang, the credibility of the data and analysis in relation to the other provinces is enhanced.

\section{International food aid}

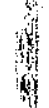

North Korea has been a major international food aid recipient since 1995. The largest food aid deliveries were in 2001 and amounted to a million tonnes of food aid worth some US $\$ 240$ million through the UN World Food Programme in that year (see for instance WFP 1997, 1999, 2002b,c; 2003b; WFP DPRK nd). Food aid was targeted to the provinces to which humanitarian agencies had access and universally, within the accessible provinces, towards all children under 7 years old. NGOs provided a relatively small proportion of humanitarian assistance - some US\$70 million in 2001 - and tended to provide complementary assistance to the food aid provided by WFP, for example medical assistance, support for agriculture and winter clothing for children (United Nations 2003: 72). The data used in this essay are drawn from the provinces to which humanitarian 
personnel of months f everyday nly carried overnment is at which ie resident spposed to

gricultural ormer cat: data thus mkin city. show an on figures lot low in to malnuJngyang's ent figure :onditions was 1 per 02 ).

) research indicates rtance of I activity, h noting, $y$ obvious ralysis in

995. The tonnes of ramme in PRK nd). icies had children tanitarian ementary ssistance, ins 2003: anitarian

agencies delivered food aid. All children under seven in all provinces covered in this analysis were equally targeted for assistance. All children under 7 years old in the provinces accessible to humanitarian agencies were allocated the same ration irrespective of the province in which they lived. It is children under 7 years old whose nutritional status provides the key indicator for this assessment. Given the equality of treatment given to all children under 7 years old by the World Food Programme, the major food aild provider, international food assistance is not likely to be a key variable in explaining different nutritional outcomes between provinces.

\section{Why was there such a high malnutrition rate in the breadbasket province of South Hwanghae relative to other provinces and relative to its agricultural capacity?}

Poverty in South Hwanghae does not reflect an inability of the province to grow enough food to feed its population. South Hwanghae recovered relatively well from the famine years as we can see from Figure 3. Instead poverty is more likely the result of the lack of opportunities for South Hwanghae's citizens to use market opportunities available to others sectors of the population. First, the population of South Hwanghae had little regular contact with foreigners through whom they could earn or obtain hard currency and thus few opportunities to buy and sell food. Second, and control over local populations and non-state-sanctioned trading opportunities was relatively straightforward for the Pyongyang-based central state institutions. The combination of these two variables negatively correlated to undermine the ability of the population of South Hwanghae to feed itself. Conversely the ease of access by Pyongyang and the central state machinery to South Hwanghae facilitated the extraction of South Hwanghae's grain production, probably to feed the population of Pyongyang. Figure 3 shows that South Hwanghae has been able to produce enough grain to cover the needs of the population but it does not produce enough to cover the needs of its population and to support major grain transfers out of the province.

\section{Little contact with foreigners and few non-state-sanctioned opportunities to buy and sell food}

South Hwanghae is a populous province of 2.3 million-at 2005 (WFP 2006). The available data for 2005 for the approximately 85 per cent of the population living in 17 of the counties indicate that the farming population for these 17 counties was an average of just under 60 per cent for each county (WFP 2006). ${ }^{17}$ DPRK government data underestimates the farming population as it does not include the large state farming sector in Kwail. DPRK population statistics count state farm workers (that is, non-cooperative farm workers) as 'non-farmers' for accounting purposes because state farms are not designed to produce food for consumption, but instead are specialist producers of seeds or monocrops. Kwail state farms for instance produce mainly fruit. ${ }^{18}$ South. Hwanghae was (and is) a predominantly farming province. 
Opportunities for access to foreigners and the ability to earn or obtain hard currency are few in South Hwanghae. Opportunities for trade and access to significant markets might have been expected to be concentrated in the port city of Haeju situated on the DPRK's west coast less than 20 kilometres from the South Korean land border. Haeju City is one of the DPRK's least important ports, however, handling less than 10 per cent of the DPRK's foreign trade compared to the major west-coast port of Nampo ( 29 per cent of trade) and the major east-coast port of Chongjin (24 per cent). ${ }^{19}$ Its nominal berthing capacity is small - with an ability to accommodate just 10,000 tonnes of shipping - and there has been no evidence of major upgrading in order to increase its capacity, unlike for instance in the port of Nampo, the country's main port city which is located north of Haeju, near Pyongyang. ${ }^{20}$ Haeju City's proximity to South Korea - it shares a land and sea border - is the main factor preventing the port's expansion. Foreigners are strictly surveilled in the port town to prevent contact with the population - as are the local population monitored to try to prevent defection by sea. Twelve of South Hwanghae's counties either border South Korea directly or have a sea coast through which South Korea could be relatively easily accessed if the border and the coastline was not heavily militarised. Defection by land and sea is virtually impossible given the extent of the militarisation of the border.

There are no major tourist destinations in this province, unlike for instance Kangwon, which is the location for the Hyundai tourism investment at the scenic Mount Kumgang that attracts hundreds of thousands of foreign, mainly South Korean tourists. The province has little of significance in terms of manufacturing or extractive industries in which foreigners might be tempted to invest. Some aid workers visit South Hwanghae but are not based in any of the towns or cities in the province.

Given the absence of industrial development and its absence of major trade ports or border trade possibilities, there are few opportunities for the population to engage in petty or commercial trade such as to obtain hard currency. The South Hwanghae population has thus a relative inability to obtain food and income from markets together with a relative insulation from foreigners and access to hard currency.

\section{Control over the local populations by the central state machinery}

The counties of South Hwanghae are a short driving distance from Pyongyang and connected to the capital by a reasonably good road network. Central state officials and the military are thus more easily able to exert control over the province by virtue of proximity. We have already seen that Pyongyang is not able to feed its population yet its population suffers the least amount of malnutrition in the country. Given the proximity of South Hwanghae to Pyongyang, the capacity of the government to impose control in the province because of proximity and accessibility, it is most likely that South Hwanghae continues to transfer a significant portion of agricultural production to Pyongyang. The province thus relies on domestic provincial food production to cover basic necessities and to avoid starvation. If grain transfers are made to Pyongyang, there will be insufficient grain to cover the basic requirements of the population. 
hard curignificant : Haeju h Korean however, ed to the zast-coast Il - with has been inlike for $s$ located orea - it xpansion. the popuin by sea. $y$ or have sed if the $\mathrm{d}$ and sea er.

: instance nt at the $\mathrm{n}$, mainly manufacto invest. the towns

ajor trade opulation sncy. The food and gners and

syang and e officials ovince by to feed its on in the apacity of and accessignificant $s$ on domstarvation. n to cover

\section{Why is North Hamgyong better off than its agricultural ranking would suggest?}

Large parts of North Hamgyong remain desperately poor and wasting in the province continued to be at an unacceptably high level (see Figure 4). Nevertheless, Figure 9 shows that North Hamgyong's population was faring better than the breadbasket provinces of South Hwanghae and North Hwanghae in 2002 and 2004 in terms of the relative nutritional status of the population to agricultural production. Why was this?

Poverty in North Hamgyong is partly a reflection of an inability of farmers to produce enough food to feed the population of the province. The fact that North Hamgyong's population is not even worse off, however, is due to the market opportunities that the population is able to use and the difficulties for Pyongyang in exerting political controls in this province. The population of North Hamgyong benefited from (1) regular contact with foreigners, especially Chinese traders and those involved in commerce and shipping, through whom they could earn or obtain hard currency and also gain opportunities to buy and sell food, and (2) the inability of the Pyongyang military/state/party institutions to exert control over local populations and local trading. The combination of these two factors positively correlated to provide opportunities for the population of North Hamgyong to obtain food and other necessities outside of provincial production.

\section{Regular contact with foreigners and multiple non-state sanctioned opportunities to buy and sell food}

In 2005 North Hamgyong had a similar size population to South Hwanghae at around 2.3 million (WFP 2006). North Hamgyong is comprised of one major city, Chongjin, which was divided into six city districts (a city district having the equivalent local government status to the county) and an additional 14 counties. In 2005 socio-economic datawwas available for 17 of the 20 counties (including Chongjin's six city districts) amounting to 84 per cent of North Hamgyong's population. Of the 17 counties the average farming population was just 21 per cent for each county - leaving nearly 80 per cent of the population of those 17 counties to find their food from income, trade or aid (WFP 2006). ${ }^{21}$

One difference between North Hamgyong and South Hwanghae is that seven of North Hamgyong's 14 counties border onto a long border with China that is largely unmilitarised and therefore relatively porous (Smith 2005c). North Hamgyong borders on China's Korean speaking region of Yanbian whose Chinese citizens are ethnic Koreans. The population in the northern counties of the province are likely to have relations inside China. North Hamgyong continues to be major source of unauthorised migration into China - demonstrating the desperation of numbers of North Hamgyong's citizens, the relative openness of the China border and the continued pull factor of Chinese prosperity and potential for economic opportunity for North Korea's impoverished citizens.

Large parts of North Hamgyong are open to trade and physical communication with China and other countries via land borders and the significant local economic 
activity in shipping. The population living in the industrialised coastal strip and the border counties of North Hamgyong has proximity to foreigners and consequently access to hard curreney as well as some opportunities to buy and sell food and other goods.

North Hamgyong is also home to the busy international port town of Chongjin. Chongjin is the country's second most important port in terms of trade volumes, with its ships regularly calling into Chinese ports as well as into neighbouring ports of Vladivostok in Russia and Niigata in Japan. ${ }^{22}$ Chongjin is linked with Russia by rail and with China by road. Chongjin, although not bordering China, is home to a Chinese consulate that looks after the interest of the large numbers of Chinese traders active in the province.

\section{Control over the local populations by the central state institutions}

Prior to the economic breakdown of the early 1990s, North Hamgyong's population made their living from the large industrial plants, including the steel and cement works in Chongjin, Kimchaek and Undok as well as by working in the mines, for instance in Musan. North Hamgyong's formerly privileged industrial proletariat became some of the most vulnerable to starvation in the entire country in the famine years as the big industrial plants closed or shed thousands of their workforce. The province has little arable land and the pre-famine system of grain redistribution collapsed and ceased to function from the mid 1990 s onwards. The state had lost capacity to enforce nationwide food allocation and distribution mechanisms and in so doing had ended grain redistribution to North Hamgyong from grain 'surplus' provinces. The central state's incapacity facilitated the institutionalisation of market economic activity as the primary source of goods and food after the famine years during which the provincial population had turned to bartering, swapping and selling in order to ensure its very survival. In the absence of governmental capacity the local officials had little choice other than to sanction self-help mechanisms. The North Korean state did not regain capacity to feed the provincial population or to control the population in the way it had prior to the famine years, and market mechanisms, fed by market opportunities generated by denomic growth in nearby China, remained the primary economic nexus for North Hamgyong's inhabitants.

The province benefits from its physical distance from Pyongyang in that road and rail links and telecommunications infrastructure are primitive, thus making it difficult for Pyongyang to engage in effective surveillance over the population. The normal driving time from Pyongyang to Chongjin, even when the weather is clement, is three days. The difficulties are further compounded for Pyongyang because of the relatively dispersed nature of the population in each of the counties. Of North Hamgyong's 20 counties (including the six city districts of Chongjin), the average population density as at 2001 was 141 persons per square kilometre. This figure was much lower than the average population density for the counties in the DPRK at 2001 at 331 persons per square kilometre (data compiled from UNICEF 1997; Central Bureau of Statistics 1998; USAID, 1998, UNICEF 1999a; Flood Damage Rehabilitation Commission 2000, 2001, 2002; WFP $2000,2001)$. Much of the province is mountainous with a poorly functioning 
strip and ad conse$I$ and sell

Thongjin. volumes, ghbouring lked with ag China, numbers

g's popusteel and ing in the industrial he entire housands re-famine I the mid allocation ibution to ncapacity : primary zial popue its very had little I state did ropulation by market ained the

that road Is making spulation. veather is yongyang : counties. 'hongjin), silometre. ounties in iled from UNICEF 02; WFP unctioning

road and railway system. In winter, with temperatures that can descend to $-40^{\circ} \mathrm{C}$, much of the province can be difficult to access.

\section{Why was South Hamgyong consistently the poorest province in the post-famine period?}

South Hamgyong is similarly industrialised, similarly located in the remote northeast yet relative to North Hamgyong is better able to feed it population from its own production. Research suggests that even in the famine period South Hamgyong was not the worst-off province in terms of ability to feed its population (Schwekendiek 2008). Nevertheless, South Hamgyong maintained the position of worst performer in terms of nutritional indicators in the post-famine period (see Table 2). South Hamgyong did fare somewhat better in terms of the relationship between nutritional status and agricultural self-sufficiency. Figure 9 shows, somewhat surprisingly, that the nutritional status of the population relative to the agricultural capacity of the province was better than either of the breadbasket provinces of North Hwanghae and South Hwanghae, or the mixed (agriculture/ industry) province of North Pyongan.

The explanation for South Hamgyong's poverty does not lie solely in its poor agricuitural capacities. There is certainly insufficient grain produced to feed the population and, similarly to North Hamgyong, there is no indication of systematic grain redistribution from other provinces since the early 1990s. In this section I show that the population of South Hamgyong had limited opportunities to engage in trade with foreigners and conversely, the Pyongyang central state institutions' ability to exert control over local populations and local trading was relatively more achievable than that possible in the neighbouring province of North Hamgyong. The combination of these two factors negatively correlated to diminish opportunities for the population of South Hamgyong to obtain food and other necessities outside of provincial production. Few market opportunities for South Hamgyong's citizens combined with chronic food shortages, means that South Hamygyong's population continue to be the poorest of all North Korea's provincial populations. Arguably, however, South Hamgyong's nutritional indicators would be showing even worse levels of malnutrition were it not for the limited market opportunities available to the population since the famine years.

\section{Limited opportunities to engage in trade with foreigners}

In 2005 South Hamgyong had a population of just over 3 million (WFP 2006). South Hamgyong is comprised of one major city, Hamhung, as well as 17 counties. In 2005, similarly to North Hamgyong, socioeconomic data were available for 84 per cent of the population. Available data were for 12 of the 17 counties plus parts of the 2001 administrative city administration of Hamhung, including the large suburb of Hungnam port. ${ }^{23}$ Of the 12 counties, the average farming population was 37 per cent but this figure masks big variations: Hamhung, with its large total population, has a farming population of just 9 per cent, with Sinpo at 11 per cent. At the other end of the scale Hamju and Doksong have 60 per cent farming family populations. 
Hamhung is a port city but the port is not significant in terms of volume of foreign trade. Its main cargoes were bulk fertiliser and chemicals for the now run-down fertiliser and agricultural chemicals and pesticides factories. ${ }^{24}$ Hamhung and its port of Hungnam have not been the target of port investment as has been, for instance, Nampo. Hamhung has not therefore provided similar economic opportunities to the local population from foreign trade as have Nampo and Chongjin. On the other hand, Hamhung does host foreign traders from China and elsewhere and is less subject to surveillance than Haeju in South Hwanghae, giving local people some opportunities for trade.

There are fewer market opportunities for South Hamgyong's citizens than for their compatriots in or North Hamgyong because they do not share borders with any foreign country. The China border is more accessible than to those who live in the south-west of the country but it is only accessible through mountainous roads in often dangerous conditions. Public transport is virtually non-existent and fuel and motorised transport is inaccessible to the vast majority.

\section{Pongyang's ability to exert control over local populations}

The populous coastal strip of South Hamgyong is easier to access from Pyongyang than its northern neighbour North Hamgyong. A main arterial road leads from Pyongyang to the east coast port city of Wonsan (in Kangwon province) and Hamhung is a relatively easy drive from Wonsan northwards. It is consequently physically easier for Pyongyang to maintain control over the local parties and the population (although not as easy as in the west coast provinces).

\section{Market opportunity, poverty and the provinces}

It has been shown 'that relative deprivation between provinces was not a direct function of relative agricultural self-sufficiency'. It has also been shown that the scale of disproportion between agricultural self-sufficiency and nutritional status is surprising. The author is cautiously confident that these conclusions are robust, even given the limitations of the data. Poverty in the post-famine DPRK can be accounted for as the product of the relationship between comparative advantage, including agricultural self-sufficiency, and market opportunity. Further empirical work that traces market opportunities for different social groups would be useful to gaing knowledge about inequality and poverty in the DPRK.

\section{The implications for policy makers}

An obvious implication of the above research is that market opportunities need to be encouraged and supported in economic policy making towards the DPRK. Another, perhaps counterintuitive, conclusion is that, in a continuing environment of scarce resources and very large needs for assistance, humanitarian policy is required to be directed towards the provinces that are capable of feeding their populations through their own agricultural production as much as to those with 
volume of or the now factories. $^{24}$ investment led similar e as have ign traders 1 Haeju in us than for orders with those who ountainous xistent and

rom Pyonerial road gwon provards. It is I over the west coast

ot a direct vn that the onal status usions are ine DPRK mparative sportunity. ent social erty in the

ies need to he DPRK. vironment 1 policy is :ding their those with less agricultural capacity. In any case, provincial agricultural capacity, or more precisely the absence of it, should cease to be used as a major indicator of humanitarian need of provincial populations in North Korea.

\section{Notes}

The author thanks Mihail Petkovski for help on the quantitative analysis and also Ambassador Donald Gregg, Fred Carrière and all at the Korea Society, Karin Lee and John Park at the United States Institute of Peace working group on Korea, Brad Babson and the SAIS Korea-US working group at Johns Hopkins University, Jong Park and the Korea-America Sharing Movement and the State department officials, Carter Eckert, students and staff at Harvard University who kindly hosted presentations of an earlier version of this paper in New York, Washington DC and Boston.

1. South Korean analysts of this phenomena include Jae-Jean Suh (2005) and Sung Chull Kim (2006). More recently US analysts have become aware of the marketisation process. See for example Haggard and Noland (2007).

2. For a representative and influential work that explicitly argues that 'interpretation' is the best we can do in terms of economic analysis of the DPRK given "less reliable information is available about the DPRK than perhaps any other country in the modern world', see Eberstadt (1999: 4-5). By 2004 the same author was still reiterating that 'the analysis of the modern North Korean economy has always been hampered by the extraordinary paucity of reliable data that might facilitate independent assessments'. See Eberstadt (2007: 280) from a chapter rewritten from a paper first given in 2004.

3. There is a debate as to whether the North Korean famine should be considered as a food availability failure (that is, a problem of gross food shortages) or a failure of food accessibility (that is, a consequence of available food not being received by hungry sectors of the population despite potential availability in the country). For an argument supporting the former perspective, see Lee (2003). For a perspective highlighting food inaccessibility as the most important causative factor, see Haggard and Noland (2007).

4. For detailed discussion of the principle of 'self-reliance' or Juche underpinning state ideology, see White (1975).

5. See for instance the collection of articles and pieces of information on North Korean Economy Watch, on http://www.nkeconwatch.com.

6. For explicit reference to this baseline figure, see FAO/WFP $(1999,2002)$.

7. Useful data and analysis on contributory factors to malnutrition can be found in the UNICEF multiple indicator cluster surveys, the three WFP/UNICEF/DPRK government nutritional surveys and the UNICEF Situation Analysis on women and children in the DPRK. Sanitary facilities clearly were consequential in determining vulnerability. The UNICEF (and WFP/EU) large surveys and NGO water/sanitation surveys show problematic water/sanitation facilities throughout the country. Those receiving piped water supplies (about 80 per cent of the population) were likely to have more compromised water/sanitation facilities than if water came from well sources. Pyongyang's water supply and sanitation infrastructure was degraded to such an extent for instance that UNICEF argued in 1999 that all the conditions were in place for an epidemic of water bome disease. Given Pyongyang consistently records better nutritional status than the rest of the country and given the national surveys reports a pretty uniform degradation of water/sanitation facilities I have not therefore included water/sanitation as a key causative factor in provincial difference. See UNICEF (1999a, b), EU, UNICEF and WFP (in partnership with the Government of DPRK) (1998), Central Bureau of Statistics (2002) and Bureau of Statistics/Institute of Child Nutrition (2005).

8. For more detail on local government structures see UNICEF (1999a).

9. UNICEF (1998) shows no discernible difference between nutritional outcomes in rural and urban areas for children under 7 years-old (after at least 6 years of famine and acute food shortages). See also Smith (2005a: 45-76).

10. There is much speculation on the Songbun class system, which is supposed to divide the population into $51-$ 64 different categories but almost no hard evidence. The most likely interpretation is that North Korea did indeed attempt a categorisation of its population after the Korean war, but it is not clear at all to what extent this categorisation was institutionalised and to what extent it persisted after the 1950s. The most extensive account in English can be found in Kagan et al. (1988: 34-45). This report also discusses the ration system $(189-199)$. The report notes in its introduction the limitations of its data foundation.

11. On the persistence of food shortages, see Lee (2003). 
12. Party membership figures given at two million in 1975 from a total population of around 16 million. If about half the population were men and about half were under 25 , this leaves around 2 million. These are of course crude numbers but they illustrate the point hat this was a mass party, not a party of a small elite. For party figures, see Lee (1978: 126). For populatibn figures, see Eberstadt and Banister (1992: 37). The gender breakdown of party membership is extrapolated from conversations $I$ had with North Korean officials in 1998.

13. The FAO conducted food and crop assessments regularly between 1995 and 2004 and was then refused permission to carry out these assessments until 2008. See FAO/WFP (2004). At the time of writing the 2008 FAO Crop and Food Supply Assessment report is pending publication.

14. Data on cultivable land per province from WFP (2002).

15. There remains a debate in the literature as to which province was worst off during the famine years of the mid 1990s. In 1999 Andrew Natsios commented on the relative ability of North Hamgyong's inhabitants to cross the China border to obtain support and argued that Hamhung in South Hamgyong was the 'the city most devastated by the famine'. Food refugee movement across the border may have been a lag factor in the wake of famine, however, with North Hamgyong's population crossing the border as a last resort when it became obvious that the state was not going to help them, and many people had died of hunger and disease (see Natsios 1999). For a summary that points to the 'consensus' that North Hamgyong was the worst hit province during the famine, see Haggard and Noland (2005).

16. There remains a debate about famine figures. The most rigorous research is Lee (2003).

17. Data on farming population not available for Ongjin, Ryongyon and Sinchon.

18. I visited Kwail in May 2001 as part of a UN WFP monitoring team and spoke with county officials and local farmers. The county had recently been opened for humanitarian assistance. The county had had a zero spring crop production and was reliant on WFP assistance to supplement a meagre diet. See also Food Aid Liaison Unit (2002).

19. See http://www.asiatradehub.com/n.korea/ports.asp.

20. See http://www.asiatradehub.com/n.korea/ports.asp.

21. Data on farming population not available for Hwadae, Myongchon and Yonsa.

22. http://www.asiatradehub.com/n.korea/ports.asp.

23. No information is available for Bujon, Yodok, Jangjin, Hochon and Kowon in the 2005 data and there is also a discrepancy of 64,000 in the totals for 2005 of accessible counties in South Hamgyong and total population of South Hangyong. This is likely because of reorganisation of Hamhung city and possibly because one city district is also excluded from the accessible counties in 2005. This is speculation, however, as $I$ have not been able to locate adequate data sources to explain this missing 64,000. See WFP (2006). Data for 2001 compiled from Flood Damage Rehabilitation Commission (2001, 2002), WFP (2001).

24. http://www.asiatradehub.com/n.korea/ports.asp.

\section{References}

Ahn, C.-Y. (ed). (2007), North Korea Development Report 2002/03 (Seoul: KIEP).

Asad, A., Murthi, M., and. Yemtsov, R. (2005); Growth, poverty, and inequality in Eastern Europe and Central Asia (Washington, DC: World Bank).

Center for Contemporary International Problems (1997), 'The DPRK Report No. 8, July-August 1997', Moscow (reproduced as North East Asia Peace and Security Network Special Report, mimeo, but copied from NAPSNET website, 30 September 1997)

Central Bureau of Statistics (2002), Report on the DPRK nutrition assessment 2002, mimeo, Juche 91, 20 November, Pyongyang.

Central Bureau of Statistics/Institute of Child Nutrition (2005), DPRK 2004 nutrition assessment report of survey results, mimeo, Pyongyang.

Central Bureau of Statistics/UNDP (1998). 'Thematic Roundtable Meeting on Agricultural Recovery \& Environmental Protection For the DPRK', Pyongyang.

Cho, J.-A. (2007), 'The Changes of Everyday Life in North Korea in the Aftermath of their Economic Difficulties', KINU, Seoul.

Eberstadt, N. (1999), The end of North Korea (Washington, DC: American Enterprise Institute Press).

Eberstadt, N. (2007), The North Korean economy: between crisis and catastrophe (New Brunswick, NJ: Transaction). 
nillion. If about se are of course elite. For party 7). The gender ean officials in Ien refused perriting the 2008

years of the mid bitants to cross : city most devin the wake of vhen it became nd disease (see rsst hit province

icials and local Id a zero spring od Aid Liaison

nd there is also otal population scause one city I have not been 2001 compiled

se and Central

997', Moscow $t$ copied from

Juche 91, 20

?port of survey

:ry \& Environ-

eir Economic

ress)

runswick, NJ:
Eberstadt, N., and Banister, J. (1992), The population of North Korea (Berkeley, CA: University of California Press).

EU, UNICEF and WFP (in partnership with the Government of DPRK) (1998), Nutrition survey of the Democratic People's Republic of Korea (Rome/Pyongyang: WFP).

FAO/WFP (1999), Special Report: Food and crop supply assessment mission to the Democratic Peoples' Republic of Korea, mimeo, 8 November.

FAO/WFP (2002), 'Special Report: Food and crop supply assessment mission to the Democratic Peoples' Republic of Korea', mimeo, 29 July.

FAO/WFP (2004), Special Report: Crop andffood supply assessment mission to the Democratic Peoples' Republic of Korea, mimeo, 22 November.

Flood Damage Rehabilitation Commission (2000), Flood Damage Rehabilitation Commission statistics as reported to WFP, Pyongyang.

Flood Damage Rehabilitation Commission (2001), Flood Damage Rehabilitation Commission - via WFP, Pyongyang.

Flood Damage Rehabilitation Commission (2002), Flood Damage Rehabilitation Commission - via WFP, Pyongyang.

Food Aid Liaison Unit (2002), Annual Report 2001 (Pyongyang: FALU).

Frank, R. (2006), 'Can Economic Theory Demystify North Korea?' Korea Review of Intemational Studies, 9 (1), pp. 3-26.

Frank, R. (2008), 'North Korea: Domestic Politics and Economy', in R. Frank et al. eds, Korea 2007: politics, economy, and society (Leiden: Brill), pp. 25-35.

Haggard, S., and Noland, M. (ed). (2005), 'Hunger and Human Rights: The Politics of Famine in North Korea', US Comittee for Human Rights in North Korea, Washington, DC.

Haggard, S., and Noland, M. (2007), Famine in North Korea: markets, aid and reform (New York: Columbia University Press).

Haggard, S., and Noland, M. (2008), 'Authors' Response: Famine in North Korea - A Reprise', Asia Policy, 5 , pp. 203-21.

Hoare, J.E., and Pares, S. (2005), North Korea in the 21st century: an interpretative guide (Folkestone: Global Oriental).

International Journal of Korean Unification Studies (1992-2008), International Journal of Korean Unification Studies, successive issues, KINU, Seoul. Available from: http://www.kinu.or.kr/eng/pub/ pub_03_01.jsp?category=11 [Accessed 26 April 2009].

Kagan, R., Oh, M., and Weissbrodt, D. (1988), Human rights in the Democratic People's Republic of Korea (Minneapolis, MN/Washington, DC: Asia Watch and the Minnesota Lawyers International Human Rights Committee), pp. 34-45.

Kim, S.C. (2006), North Korea under Kim Jong Il: from consolidation to systemic dissonance (Albany, NY: State University of New York Press).

Kim, Y.-Y. (ed). (2007), 'A Study on the Reality and Prospect of Economic Reform in North Korea: Tasks for Successful Transformation of the North Korean System', KINU, Seoul.

KINU Insight (2007-8), KINU Insight, successive editions KINU, Seoul. Available from: http://www. kinu.or.kr/eng/pub/pub_01_01.jsp?category=14 [Accessed 26 April 2009].

Korea Economic Institute (2008), North Korea's economy: economic data (Washington, DC: Korea Economic institute).

Korea Economic Institute (nd), various paperts, Washington, DC. Available from: http://www.keia.org/paper_ series.php [Accessed 26 April 2009]. Th

Lankov, A. (2008), 'Famine in Paradise', Asia Policy, 5, pp. 193-6.

Lee, C.M. (2008), 'The Emperor's Famine', Asia Policy, 5, pp. 189-93.

Lee, C.-S. (1978), Korean Workers' Party: a short history (Stanford, CA: Hoover Institution).

Lee, S. (2003), Food shortages and economic institutions in the Democratic People's Republic of Korea, unpublished doctoral thesis, Department of Economics, University of Warwick.

Lee, Y.-S., and Yoon, D.R. (2004), The structure of North Korea's political economy: changes and effects (Seoul: KIEP).

McNally, C.A. (ed). (2007), China's emergent political economy: capitalism in the dragon's lair (London: Routledge).

Nathanail, L. (1996), Food and nutrition assessment of the DPRK (Rome: World Food Programme) 
Natsios, A. (1999), The politics of famine in North Korea, USIP Special Report (Washington, DC: United States Institute of Peace Press). Available from: http://www.usip.org/pubs/specialreports/sr $990802 . p d f$ [Accessed 26 April 2009].

Reed, E.P. (2008), 'Famine's Aftermath: Retrenchment or Reform?' Asia Policy, 5, pp. 186-9.

Schwekendiek, D. (2008), 'The North Korean Standard of Living During the Famine', Social Science and Medicine, 66 (3), pp. 596-608.

Smith, H. (1999), "'Opening up" by default: North Korea, the Humanitarian Community and the Crisis', Pacific Review, 12 (3), pp. 453-78.

Smith, H. (ed). (2002), 'La Corée du Nord vers l'économie de marché: faux et vrais dilemmas', Critique Internationale, 15, pp. 6-14.

Smith, H. (2005a), Hungry for peace: intemational security, humanitarian assistance and social change in North Korea (Washington, DC: United States linstitute of Peace Press).

Smith, H. (2005b), 'The disintegration and reconstitution of the state in the DPRK', in S. Chesterman, M. Ignatieff, and R. Thakur eds, Making states work (Tokyo: United Nations Press).

Smith, H. (2005c), 'North Koreans in China: defining the problems and offering some solutions', in T. Akaha and A. Vassilieva eds, Crossing national borders: human migration Issues in Northeast Asia (Tokyo: United Nations Press).

Smith, H. (2008), 'North Korea as the Wicked Witch of the East: Social Science as Fairy Tale Famine', Asia Policy, 5, pp. 197-203.

Suh, J.-J. (2005), 'The Transformation of Class Structure and Class Conflict in North Korea', International Journal of Korean Unification Studies, 14 (2), pp. 52-84.

Suh, J.-J. (2008), Economic Hardship and Regime Sustainability in North Korea, KINU, Seoul

UNICEF (1997), 'Emergency Situation Analysis' (based on the 1993 Census), UNICEF, Pyongyang.

UNICEF (1998), The multiple indicator cluster survey in the Democratic People's Republic of Korea, 1998, mimeo, UNICEF, Pyongyang.

UNICEF (1999a), An analysis of the situation of children and women in the Democratic People's Republic of Korea 2000, UNICEF DPRK, Pyongyang, December.

UNICEF (1999b), Social statistics: DPRK, UNICEF DPRK, Pyongyang.

UNICEF/Institute of Child Nutrition (1988), Working paper on pilot survey in Kangwon province, mimeo, UNICEF, Pyongyang, June.

United Nations (2003), Common country assessment, mimeo, United Nations, Pyongyang, February.

USAID (1998), 'Humanitarian Response Planning Map -DPRK', USAID, Washington, DC.

WFP (1997), Emergency Operation DPR Korea No. 5710.02: Emergency food assistance following floods, WFP, Rome.

WFP (1999), WFP operations in DPR Korea as of 14 July 1999, WFP, Rome (undated but 1999).

WFP (2000), The World Food Programme review of operations in 2000, WFP, Pyongyang.

WFP (2001), The World Food Programme review of operations in 2001, WFP, Pyongyang.

WFP (2002a), DPRK review of operations in 2001, WFP, Pyongyang.

WFP (2002b), DPR Korea update No. 40, WFP, Pyongyang, May.

WFP (2002c), DPR Korea Update No. 41, WFP, Pyongyang. June.

WFP (2003a), Statistics of DPRK population 2002, mimeo, WFP, Pyongyang.

WFP (2003b), DPR Korea Update No. 52, WFP, Pyongyang, May.

WFP (2006), DPRK population statistics, DPRK government as submitted to UN WFP, mimeo, WFP, Pyongyang.

WFP DPRK (nd), The public distribution system, mimeo, WFP, Pyongyang (undated but obtained by author from WFP, Pyongyang, February 2003).

White, G. (1975), 'North Korean Chuch'e: The Political Economy of Independence', Bulletin of Concerned Asian Scholars, $7(2)$. 